Archived version from NCDOCKS Institutional Repository http://libres.uncg.edu/ir/asu/

Roy, J. (2011). Is the WTO mystery really solved?. Economics Letters, 113(2), 127-130.

doi:10.1016/j.econlet.2011.06.010

\title{
Is the WTO mystery really solved?
}

\section{Jayjit Roy}

\begin{abstract}
:
The WTO's impact on bilateral trade remains puzzling due, in part, to previous studies' failure to simultaneously address three issues: inclusion of zero trade, proper controls for multilateral resistance, and proper membership definition. Addressing all fails to suggest a positive effect.
\end{abstract}

Keywords:

World Trade Organization, Gravity model, Three issues 


\section{Introduction}

Ever since Rose (2004) found little evidence of the World Trade Organization's role in enhancing its members' bilateral trade, a number of studies have employed the gravity model and attempted to solve this (p. 112) "interesting mystery". Unfortunately, all (to my knowledge) either estimate a theoretically inconsistent model by omitting controls for Anderson and van Wincoop's (2003) multilateral resistance variables, or risk a potential sample selection bias by dropping country-pairs with zero bilateral trade. While the estimates in Rose (2004) suffered from both, Tomz et al. (2007) fail to address either, but claim to have solved the mystery by redefining the set of GATT or WTO participants. According to the authors, Rose's (2004) failure to capture the role of colonies, de facto members and provisional members as nonmember participants led to a downward bias in the estimated WTO coefficients. Using a new definition of participation, which includes both nonmember participants and formal members, they find positive and significant effects of WTO participation. Next, Subramanian and Wei (2007, p. 173), allude to "four asymmetries in the system" and consider the WTO to have done a "splendid" but "uneven" job in promoting trade. However, they exclude zero trade observations. More recently, Liu (2009) distinguishes between the WTO's roles at the intensive and extensive margins. While the former refers to promoting trade among existing trading partners, the latter involves encouraging new trading relationships. According to Liu (2009), the aforementioned studies underestimate the effects of membership by omitting the zero trade observations and thereby neglecting the extensive margin. While Liu (2009) finds a positive and significant effect of formal membership after including the zeros, the result remains questionable due to lack of proper controls for the theoretically motivated multilateral resistance terms. The remoteness proxy used is considered by Anderson and van Wincoop (2003, p. 170) to be "at odds with the theory".2 Finally, Eicher and Henn (2011, p. 146), control for multilateral resistance and "search" for "WTO trade effects" by employing the participation definition. However, they neglect the extensive margin.

This paper contributes to the literature by estimating a theoretically consistent gravity model while avoiding the potential sample selection bias. In addition, sensitivity of the estimates to the two definitions of WTO membership - with and without the nonmember participants - is also analysed. Using the data from Liu (2009) at five-year intervals, the results are striking. In the full sample, the use of neither definition finds WTO countries to engage in significantly greater bilateral trade. Separate regressions for each decade, which also control for bilateral fixed effects, find membership to significantly promote trade only upon using Tomz et al.'s (2007) participation definition during the 1950 to 1960 period. Hence, existing claims to have overturned Rose's (2004) findings appear tenuous. In fact, if the lack of a positive and significant WTO effect is indeed a mystery, then the prospect of solving it by estimating a gravity model seems unlikely once the zero trade observations and controls for the multilateral resistance terms are included. Accordingly, Rose's (2007, p. 2025) desire to see the question addressed beyond the "confines of the gravity model" is timely.

The remainder of the paper is organized as follows. Section 2 describes the empirical methodology. Section 3 discusses the data. 
Section 4 presents the results, while Section 5 concludes.

\section{Empirical methodology}

The gravity models are estimated in logs, with and without bilateral fixed effects. A theoretically consistent specification without bilateral fixed effects is given by

$$
\begin{aligned}
& \ln \left(T_{i j \mathrm{ti}}\right)=\beta_{0}+\beta_{1} \text { both }_{\mathrm{ijt}}+\beta_{2} \text { one }_{\mathrm{ijt}}+\beta_{3} \ln \text { dist }_{\mathrm{ij}} \\
& +\beta_{4} \text { border }_{i j}+\beta_{5} \text { landlock }_{i j}+\beta_{6} \text { island }_{i j} \\
& +\beta_{7} \text { comlang }_{i j}+\beta_{8} \text { comrelig }_{i j}+\beta_{9} \text { colony }_{i j} \\
& +\beta_{10} \text { colonizer }_{i j}+\beta_{11} \text { curcolony }_{i j t}+\beta_{12} \text { curcolonizer }_{i j t} \\
& +\beta_{13} \text { comcol }_{i j}+\beta_{14} \text { hostility }_{i j}+\beta_{15} \text { alliance }_{i j \mathrm{t}}+\beta_{16} \mathrm{CU}_{\mathrm{ijt}} \\
& +\beta_{17} R T A_{i j t}+\beta_{18} G S P_{i j t}+\beta_{19} G S P_{j i t}+\theta_{i t}+\theta_{j t}+\epsilon_{i j}+\eta_{i j t} .
\end{aligned}
$$

Here, $\mathrm{T}_{\mathrm{ijt}}$ is the real value of the imports of country $\mathrm{i}$ from country $\mathrm{j}$ at time $\mathrm{t}$; bothijt is a dummy variable taking the value one if both $i$ and $j$ are treated as WTO "members" at time $t$ and zero otherwise; one iit is a dummy variable taking the value one if either $i$ or $j$ is considered to be a WTO "member" at time $t$ and zero otherwise; distij is the distance between $i$ and $j$; borderij is a binary variable assuming the value unity if $i$ and $j$ share $a$ land border; landlockij and islandij are ordered discrete variables depicting the number of landlocked countries $(0,1$, or 2$)$ and the number of islands $(0,1$, or 2$)$, respectively, in each country-pair; comlang (comreligij) is a dummy variable taking the value one if I and $\mathrm{j}$ share a common language (religion); colony $\mathrm{y}_{\mathrm{ij}}$ (colonizerij) is a binary variable taking the value unity if $i$ has ever been a colony (colonizer) of $j$; curcolonyijt (curcolonizerijt) is a dummy variable taking the value one if $i$ is considered to be a colony (colonizer) of $\mathrm{j}$ at time $\mathrm{t}$; comcolij is a binary variable assuming the value unity if $\mathrm{I}$ and $\mathrm{j}$ were ever colonized by the same colonizer; hostilityij depicts the intensity of military conflict between $i$ and $j$; alliance ijt is a dummy variable taking the value one if $i$ and $j$ were in a formal alliance at time $t$; $\mathrm{CU}_{\mathrm{ijt}}\left(\mathrm{RTA} \mathrm{Ait}_{\mathrm{ijt}}\right.$ is a dummy variable taking the value one if $i$ and $j$ belong to the same currency union (regional trade agreement) at time $t$ and zero otherwise; GSPijt (GSPjit) is a dummy variable taking the value 1 if $i(j)$ offered preferences to j(i) under the Generalized System of Preferences at time $t$; and $\theta$ it and $\theta$ jt are the country-by-time dummies. 3 The bilateral time-varying and time-invariant unobservables are denoted by $\eta \mathrm{ijt}$ and $\epsilon \mathrm{ij}$, respectively. To facilitate comparison to prior studies, specifications replacing the country-by-time dummies with remoteness measures are also estimated.

Tomz et al.'s (2007, p. 2013) "benchmark specification" includes bilateral fixed effects. Liu (2009) also prefers including them on statistical grounds. The use of bilateral fixed effects controls for possible selection bias arising from time-invariant unobservables. Hence, the gravity equations are also estimated with bilateral fixed effects. However, given the length of the sample period, it is unlikely that any relevant unobservables remain constant over the entire period. As such, regressions are estimated separately for each decade. 
Finally, in order to include the zero trade observations, the dependent variable is

considered to be In (Tijt+1), as in Liu (2009). An alternative using In $\left(T_{i j t}+\sqrt[2]{T_{i j t}^{2}+1}\right)$ as the dependent variable is also tried (see, e.g., Kukenova and Monteiro, 2008). Since the two approaches yield very similar coefficient estimates, only the former are included.

\section{Data}

The majority of the data come from Liu (2009) for the years 1950 to 2000, at five-year intervals. Since the data includes the zero trade observations and more countries than used in Rose (2004), Subramanian and Wei (2007), or Tomz et al. (2007), it is considered to be relatively more complete by Liu (2009). However, unlike Liu (2009), here two definitions of WTO membership are considered. The first is the formal definition of WTO membership used in Liu (2009) (except for a few minor corrections made to his data). After the minor corrections, Czechoslovakia (for 1950, 1955, . . , 1990), Lebanon (for 1950), Liberia (for 1950), and Syria (for 1950) are treated as formal members. These changes rely on the sources listed in Liu (2009), and Tomz et al.'s (2007) accompanying datasets (available at http://www.stanford.edu/ -tomz/pubs/pubs.s html). The second definition is Tomz et al.'s (2007) participation-based definition. In addition, given the launch of a new WTO database on trade agreements in 2009 and some discrepancies in Liu's (2009) currency union variable, the trade agreement and currency union dummies have also been modified. Roy (2010) provides additional details.

\section{Results}

Table 1 reports results from the full sample without bilateral fixed effects. While columns (a)-(d) present estimates that rely on measures of remoteness to control for multilateral resistance, the estimates in columns (e) and (f) are obtained after controlling for the multilateral resistance terms via country-by-time dummies. Since the atheoretical specification resembles Liu's (2009) log model, the corresponding regressions include (log) GDP, (log) GDP per capita, (log) area, and year dummies in addition to remoteness and the covariates listed in (1). While column (a) simply reproduces Liu's (2009) pooled cross-section log estimates, the estimates in column (b) are obtained from the data at five-year intervals. Incorporating the corrections to the formal membership, currency union, and trade agreement dummies yields the estimates in column (c), which turn out to be very similar to the ones in columns (a) and (b). Thus, the results of the paper are not sensitive to the corrections or the use of data at fiveyear intervals.

Next, unlike the estimates in columns (a), (b), or (c), the ones in column (d) utilize the participation definition of Tomz et al. (2007). A comparison of columns (c) and (d) leads to a surprising result. Contrary to the findings in Tomz et al. (2007), the use of either definition finds country-pairs with one or two WTO members to engage in significantly greater bilateral trade, relative to country-pairs with none. Hence, the inclusion of the zero trade observations appears to render any concern over the proper WTO definition unwarranted. However, before placing too much faith in these results, one needs to properly account for the multilateral resistance terms. Accordingly, the multilateral resistance terms are controlled for in columns (e) and (f). While the WTO dummies in 
column (e) correspond to formal membership, the participation definition is used for column (f). The results differ strikingly from those reported in columns (c) and (d). In the theoretically consistent model, the use of neither definition finds evidence in

Table 1

Full sample estimates without bilateral fixed effects.

\begin{tabular}{|c|c|c|c|c|c|c|}
\hline \multirow[t]{2}{*}{ 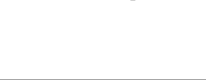 } & \multicolumn{4}{|c|}{ Omitting country-by-time dummies } & \multicolumn{2}{|c|}{ Country-by-time dummies } \\
\hline & (a) & (b) & (c) & (d) & (e) & (f) \\
\hline \multirow[t]{2}{*}{ Both } & $2.08^{*}$ & $2.048^{*}$ & $1.879^{*}$ & $1.476^{\circ}$ & -1.625 & -11.654 \\
\hline & $(0.06)$ & $(0.038)$ & $(0.038)$ & $(0.048)$ & $(2.820)$ & $(3.991)$ \\
\hline \multirow[t]{2}{*}{ One } & $0.97^{*}$ & $0.973^{\circ}$ & $0.915^{\circ}$ & $0.926^{\circ}$ & -1.312 & $-5.675^{*}$ \\
\hline & $(0.05)$ & $(0.032)$ & $(0.032)$ & $(0.048)$ & $(1.410)$ & $(1.996)$ \\
\hline \multirow[t]{2}{*}{ Log distance } & $-2.08^{\circ}$ & $-2.051^{*}$ & $-2.018^{\circ}$ & $-2.013^{\circ}$ & $-2.200^{\circ}$ & $-2.202^{*}$ \\
\hline & $(0.04)$ & $(0.021)$ & $(0.022)$ & $(0.022)$ & $(0.016)$ & $(0.016)$ \\
\hline \multirow[t]{2}{*}{ Border } & $1.13^{\circ}$ & $1.237^{\circ}$ & $1.239^{\circ}$ & $1.182^{\circ}$ & $1.049^{\circ}$ & $1.082^{\circ}$ \\
\hline & $(0.18)$ & $(0.099)$ & $(0.100)$ & $(0.100)$ & $(0.078)$ & $(0.078)$ \\
\hline \multirow[t]{2}{*}{ Number landlocked } & $-0.45^{\circ}$ & $-0.432^{\circ}$ & $-0.458^{\circ}$ & $-0.420^{\circ}$ & -0.373 & -0.316 \\
\hline & $(0.04)$ & $(0.023)$ & $(0.023)$ & $(0.023)$ & $(0.896)$ & $(0.897)$ \\
\hline \multirow[t]{2}{*}{ Number islands } & $0.24^{*}$ & $0.241^{*}$ & $0.274^{*}$ & $0.203^{\circ}$ & -5.572 & -0.618 \\
\hline & $(0.05)$ & $(0.026)$ & $(0.026)$ & $(0.027)$ & $(4.879)$ & $(4.850)$ \\
\hline \multirow[t]{2}{*}{ Common language } & $0.30^{\circ}$ & $0.266^{\circ}$ & $0.304^{*}$ & $0.312^{\circ}$ & $0.594^{\circ}$ & $0.607^{\circ}$ \\
\hline & $(0.08)$ & $(0.044)$ & $(0.044)$ & $(0.044)$ & $(0.039)$ & $(0.039)$ \\
\hline \multirow[t]{2}{*}{ Common religion } & $0.45^{\circ}$ & $0.498^{\circ}$ & $0.472^{\circ}$ & $0.535^{\circ}$ & $0.282^{\circ}$ & $0.295^{\circ}$ \\
\hline & $(0.04)$ & $(0.024)$ & $(0.024)$ & $(0.024)$ & $(0.024)$ & $(0.024)$ \\
\hline \multirow[t]{2}{*}{ Colony } & $2.84^{\circ}$ & $2.840^{\circ}$ & $2.566^{\circ}$ & $2.624^{*}$ & $2.203^{\circ}$ & $2.233^{\circ}$ \\
\hline & $(0.21)$ & $(0.121)$ & $(0.121)$ & $(0.122)$ & $(0.147)$ & $(0.147)$ \\
\hline \multirow[t]{2}{*}{ Colonizer } & $3.43^{\circ}$ & $3.466^{\circ}$ & $3.427^{\circ}$ & $3.482^{\circ}$ & $2.232^{*}$ & $2.261^{\circ}$ \\
\hline & $(0.24)$ & $(0.134)$ & $(0.133)$ & $(0.133)$ & $(0.147)$ & $(0.147)$ \\
\hline \multirow[t]{2}{*}{ Current colony } & -1.10 & $-0.784^{\cdots *}$ & -0.307 & -0.515 & $-1.041^{\circ}$ & $-1.207^{\circ}$ \\
\hline & $(0.67)$ & $(0.422)$ & $(0.431)$ & $(0.429)$ & $(0.259)$ & $(0.259)$ \\
\hline \multirow[t]{2}{*}{ Current colonizer } & -0.47 & -0.192 & 0.199 & -0.011 & -0.213 & -0.376 \\
\hline & $(0.68)$ & $(0.419)$ & $(0.423)$ & $(0.421)$ & $(0.260)$ & $(0.260)$ \\
\hline \multirow[t]{2}{*}{ Common colonizer } & $1.12^{*}$ & $1.096^{\circ}$ & $1.206^{*}$ & $1.201^{\circ}$ & $1.404^{\circ}$ & $1.408^{\circ}$ \\
\hline & $(0.07)$ & $(0.037)$ & $(0.037)$ & $(0.037)$ & $(0.035)$ & $(0.035)$ \\
\hline \multirow[t]{2}{*}{ Hostility } & $-1.48^{\circ}$ & $-1.435^{\circ}$ & $-1.380^{\circ}$ & $-1.418^{\circ}$ & $-1.507^{\circ}$ & $-1.545^{\circ}$ \\
\hline & $(0.39)$ & $(0.180)$ & $(0.182)$ & $(0.182)$ & $(0.111)$ & $(0.111)$ \\
\hline \multirow[t]{2}{*}{ Alliance } & $1.10^{\circ}$ & $1.142^{\circ}$ & $1.119^{\circ}$ & $1.264^{\circ}$ & $0.958^{\circ}$ & $1.043^{\circ}$ \\
\hline & $(0.09)$ & $(0.052)$ & $(0.052)$ & $(0.052)$ & $(0.051)$ & $(0.051)$ \\
\hline \multirow[t]{2}{*}{$\mathrm{CU}$} & $1.55^{\circ}$ & $1.535^{\circ}$ & $0.547^{\circ}$ & $0.559^{\circ}$ & $0.914^{\circ}$ & $0.953^{\circ}$ \\
\hline & $(0.15)$ & $(0.087)$ & $(0.086)$ & $(0.086)$ & $(0.071)$ & $(0.071)$ \\
\hline \multirow[t]{2}{*}{ RTA } & $1.27^{\circ}$ & $1.247^{\circ}$ & $1.536^{\circ}$ & $1.614^{\circ}$ & $1.288^{\circ}$ & $1.339^{\circ}$ \\
\hline & $(0.07)$ & $(0.050)$ & $(0.038)$ & $(0.038)$ & $(0.040)$ & $(0.040)$ \\
\hline \multirow[t]{2}{*}{ GSP (ij) } & $2.84^{\circ}$ & $2.799^{\circ}$ & $2.520^{\circ}$ & $2.560^{\circ}$ & $2.271^{\circ}$ & $2.254^{\circ}$ \\
\hline & $(0.07)$ & $(0.047)$ & $(0.047)$ & $(0.047)$ & $(0.071)$ & $(0.072)$ \\
\hline \multirow[t]{2}{*}{ GSP(ji) } & $3.10^{\circ}$ & $3.025^{\circ}$ & $2.737^{\circ}$ & $2.774^{\circ}$ & $1.889^{\circ}$ & $1.872^{\circ}$ \\
\hline & $(0.06)$ & $(0.044)$ & $(0.044)$ & $(0.044)$ & $(0.071)$ & $(0.071)$ \\
\hline $\mathrm{N}($ Both = 1) & & 74863 & 76220 & 148571 & 76220 & 148571 \\
\hline $\mathrm{N}($ One = 1) & & 126728 & 127548 & 100316 & 127548 & 100316 \\
\hline $\mathrm{N}$ & 1184525 & 244569 & 244569 & 244569 & 268911 & 268911 \\
\hline
\end{tabular}

support of the WTO's trade promoting role. On an average, country pairs with at least one WTO member engage in less bilateral trade. Interestingly, the finding is again insensitive to the definition of membership adopted although the estimates are statistically significant only when using the participation definition.

Table 2 reports the gravity estimates after including the bilateral fixed effects, but separately for each decade (e.g., the 1950 to 1960 decade uses observations from 1950, 1955 and 1960). For brevity, only the coefficient estimates of the WTO dummies using both membership definitions are presented. While specification one (labelled Spec 1 ) omits the zero trade observations and the country-by-time fixed effects, 
specification two (labelled Spec 2) only includes the former. On the other hand, specification three (labelled Spec 3) controls for the multilateral resistance terms, but continues to omit the zeros. Finally, specification four (labelled Spec 4) represents a theoretically consistent model and includes the zeros.

For specifications corresponding to Spec 1 and Spec 2, the statistically significant estimates support the WTO's trade promoting role. On average, country-pairs with both WTO members are found to engage in more bilateral trade using either definition of membership. Although the 1960 to 1970 decade (Panel II), finds country-pairs with a single formal member to engage in less bilateral trade, such coefficients are considered to be less interesting by Rose (2004). Interestingly, the adoption of a theoretically consistent model is sufficient to question the findings corresponding to Spec 1 and Spec 2. According to the estimates from Spec 3, formal members are not found to engage in significantly different volumes of bilateral trade, in any of the decades. While there is some evidence of WTO participants engaging in significantly greater bilateral trade during the 1950s, 1960s, and 1980s, the estimates are still susceptible to sample selection bias due to exclusion of the zero trade observations.

However, the estimates pertaining to Spec 4 - the preferred specification - are even more striking. Country-pairs with one or two formal members are never found to engage in significantly different volumes of bilateral trade. Even when Tomz et al.'s (2007) participation definition is used, the trade promoting role of the WTO is restricted to the 1950 to 1960 period. In fact, WTO participants are now found to engage in significantly less bilateral trade during the 1960s. Accordingly, by omitting the zero trade observations and controls for the multilateral resistance terms, existing claims to have explained Rose's (2004, p. 112) "negative result" are clearly tenuous.

Table 2

Estimates for each decade with bilateral fixed effects.

\begin{tabular}{|c|c|c|c|c|c|c|c|c|}
\hline & \multicolumn{2}{|c|}{ Formal membership definition } & \multirow[b]{2}{*}{ Spec 3} & \multirow[b]{2}{*}{ Spec 4} & \multicolumn{3}{|c|}{ Participation definition } & \multirow[b]{2}{*}{ Spec 4} \\
\hline & Spec 1 & Spec 2 & & & Spec 1 & Spec 2 & Spec 3 & \\
\hline \multicolumn{9}{|l|}{ I. $1950-1960$} \\
\hline Both & $\begin{array}{l}0.251^{*} \\
(0.084)\end{array}$ & $\begin{array}{l}0.345 \\
(0.214)\end{array}$ & $\begin{array}{l}-0.194 \\
(0.429)\end{array}$ & $\begin{array}{l}-1.414 \\
(0.942)\end{array}$ & $\begin{array}{l}0.038 \\
(0.076)\end{array}$ & $\begin{array}{l}0.789^{*} \\
(0.186)\end{array}$ & $\begin{array}{l}2.125^{\circ} \\
(0.300)\end{array}$ & $\begin{array}{l}3.585^{\circ} \\
(1.343)\end{array}$ \\
\hline One & $\begin{array}{l}0.219^{\circ} \\
(0.063)\end{array}$ & $\begin{array}{l}0.423^{\circ} \\
(0.100)\end{array}$ & $\begin{array}{l}-0.012 \\
(0.223)\end{array}$ & $\begin{array}{l}-0.442 \\
(0.471)\end{array}$ & $\begin{array}{l}0.087 \\
(0.060)\end{array}$ & $\begin{array}{l}0.676^{\circ} \\
(0.147)\end{array}$ & $\begin{array}{l}1.097^{\circ} \\
(0.144)\end{array}$ & $\begin{array}{l}2.083^{\circ} \\
(0.678)\end{array}$ \\
\hline \multicolumn{9}{|l|}{ II. $1960-1970$} \\
\hline Both & -0.024 & $1.072^{*}$ & $-2.883^{\cdots}$ & 1.119 & $0.138^{* *}$ & $0.333^{\cdots}$ & $1.043^{*}$ & -3.598 \\
\hline & $(0.053)$ & $(0.120)$ & $(1.628)$ & $(1.526)$ & $(0.082)$ & $(0.172)$ & $(0.487)$ & $(1.038)$ \\
\hline One & $-0.102^{*}$ & $0.231^{\circ}$ & $-1.542^{\cdots}$ & 0.191 & 0.033 & 0.200 & 0.474 & -1.813 \\
\hline III. $1970-1980$ & $(0.046)$ & $(0.077)$ & $(0.815)$ & $(0.767)$ & $(0.074)$ & $(0.140)$ & $(0.246)$ & $(0.535)$ \\
\hline Both & $\begin{array}{l}0.065 \\
(0.110)\end{array}$ & $\begin{array}{l}2.095^{\circ} \\
(0.269)\end{array}$ & $\begin{array}{l}-2.694^{*} \\
(0.952)\end{array}$ & $\begin{array}{l}0.627 \\
(1.487)\end{array}$ & $\begin{array}{l}0.076 \\
(0.126)\end{array}$ & $\begin{array}{l}2.861^{\circ} \\
(0.279)\end{array}$ & $\begin{array}{l}-1.406 \\
(0.903)\end{array}$ & $\begin{array}{l}-2.767 \\
(2.082)\end{array}$ \\
\hline One & $\begin{array}{l}0.112 \\
(0.091)\end{array}$ & $\begin{array}{l}1.004^{*} \\
(0.199)\end{array}$ & $\begin{array}{l}-1.287^{\circ} \\
(0.482)\end{array}$ & $\begin{array}{l}0.351 \\
(0.757)\end{array}$ & $\begin{array}{l}0.055 \\
(0.111)\end{array}$ & $\begin{array}{l}1.634^{*} \\
(0.243)\end{array}$ & $\begin{array}{l}-0.720 \\
(0.464)\end{array}$ & $\begin{array}{l}-1.242 \\
(1.055)\end{array}$ \\
\hline \multicolumn{9}{|c|}{ IV. $1980-1990$} \\
\hline Both & $\begin{array}{l}0.307^{*} \\
(0.089)\end{array}$ & $\begin{array}{l}1.488^{*} \\
(0.183)\end{array}$ & $\begin{array}{l}1.228 \\
(1.613)\end{array}$ & $\begin{array}{l}3.066 \\
(2.497)\end{array}$ & $\begin{array}{l}0.491^{*} \\
(0.149)\end{array}$ & $\begin{array}{l}1.232^{*} \\
(0.311)\end{array}$ & $\begin{array}{l}1.773^{* *} \\
(0.756)\end{array}$ & $\begin{array}{l}2.008 \\
(1.727)\end{array}$ \\
\hline One & $\begin{array}{l}0.169^{*} \\
(0.077)\end{array}$ & $\begin{array}{l}0.660^{\circ} \\
(0.144)\end{array}$ & $\begin{array}{l}0.637 \\
(0.804)\end{array}$ & $\begin{array}{l}1.513 \\
(1.258)\end{array}$ & $\begin{array}{l}0.235^{*} \\
(0.139)\end{array}$ & $\begin{array}{l}0.784^{\circ} \\
(0.277)\end{array}$ & $\begin{array}{l}0.936^{*} \\
(0.396)\end{array}$ & $\begin{array}{l}1.302 \\
(0.887)\end{array}$ \\
\hline \multicolumn{9}{|l|}{ V. $1990-2000$} \\
\hline Both & $\begin{array}{l}-0.018 \\
(0.088)\end{array}$ & $\begin{array}{l}0.151 \\
(0.124)\end{array}$ & $\begin{array}{l}-0.023 \\
(1.510)\end{array}$ & $\begin{array}{l}-0.694 \\
(1.395)\end{array}$ & $\begin{array}{l}0.203^{* *} \\
(0.101)\end{array}$ & $\begin{array}{l}0.079 \\
(0.158)\end{array}$ & $\begin{array}{l}-1.036 \\
(0.901)\end{array}$ & $\begin{array}{l}-1.753 \\
(1.650)\end{array}$ \\
\hline One & $\begin{array}{l}-0.029 \\
(0.082)\end{array}$ & $\begin{array}{l}0.142 \\
(0.107)\end{array}$ & $\begin{array}{l}-0.110 \\
(0.758)\end{array}$ & $\begin{array}{l}-0.415 \\
(0.704)\end{array}$ & $\begin{array}{l}0.082 \\
(0.094)\end{array}$ & $\begin{array}{l}-0.044 \\
(0.149)\end{array}$ & $\begin{array}{l}-0.599 \\
(0.459)\end{array}$ & $\begin{array}{l}-0.988 \\
(0.838)\end{array}$ \\
\hline
\end{tabular}




\section{Conclusion}

Rose (2004) found little evidence of the WTO's role in promoting trade. Although a number of subsequent studies claim to have solved this mystery, none has simultaneously addressed the issue of the zero trade while controlling for the multilateral resistance terms. Upon doing so, this paper arrives at striking results. Formal membership in the WTO is never found to increase bilateral trade. Once bilateral fixed effects are employed, country-pairs with one or two WTO members are found to engage in significantly greater bilateral trade only upon using Tomz et al.'s (2007) participation definition for the 1950 to 1960 period. Accordingly, existing claims to have solved Rose's (2004, p. 112) "interesting mystery" are clearly tenuous.

\section{Acknowledgments}

The author wishes to thank Daniel Millimet for helpful comments and Xuepeng Liu for generously providing the data. 


\section{References}

Baxter, M., King, R., 1999. Measuring business cycles: approximate band-pass filters for economic time series. The Review of Economics and Statistics 81, 575-593.

Bernhardsen, T., Eitrheim, Ø., Jore, A.S., Roisland, Ø., 2005. Real time data for Norway: challenges for monetary policy. The North American Journal of Economics and Finance 16, 333-349.

Cayen, J.-P., van Norden, S., 2005. The reliability of Canadian output gap estimates. The North American Journal of Economics and Finance 16, 373-393.

Christiano, L.J., Fitzgerald, T.J., 1999. The band pass filter. NBER Working Papers 7257. National Bureau of Economic Research, Inc.

Christiano, L.J., Fitzgerald, T.J., 2003. The band pass filter. International Economic Review 44, 435-465.

Clausen, J.R., Meier, C.-P., 2005. Did the Bundesbank follow a Taylor rule? An analysis based on real-time data. Swiss Journal of Economics and Statistics 127, 213-246.

Croushore, D., Stark, T., 2001. A real-time data set for macroeconomists. Journal of Econometrics 105, 111-130.

Döpke, J., 2004. Real-time data and business cycle analysis in Germany. Journal of Business Cycle Measurement and Analysis 1, 337-361.

Garratt, A., Lee, K., Mise, E., Shields, K., 2009. Real time representation of the output gap in the UK in the presence of model uncertainty. International Journal of Forecasting 25, 81-102.

Gerberding, C., Seitz, F., Worms, A., 2005. How the Bundesbank really conducted monetary policy: an analysis based on real-time data. The North American Journal of Economics and Finance 16, 277-292.

Gruen, D., Robinson, T., Stone, A., 2002. Output gaps in real time: are they reliable enough to use for monetary policy? Reserve Bank of Australia Research Discussion Paper 2002-06.

Hodrick, R.J., Prescott, E.C., 1997. Postwar U.S. business cycles: an empirical investigation. Journal of Money, Credit, and Banking 29, 1-16.

Kamada, K., 2005. Real-time estimation of the output gap in Japan and its usefulness for inflation forecasting and policymaking. North American Journal of Economics and Finance 16, 309-332. 
Marcellino, M., Musso, A., 2011. The reliability of real-time estimates of the Euro area output gap. Economic Modelling 28, 1842-1856.

Mise, E., Kim, T.-H., Newbold, P., 2005. On suboptimality of the Hodrick-Prescott filter at time series endpoints. Journal of Macroeconomics 27, 53-67.

Mitchell, J., 2003. Should We Be Surprised by the Unreliability of Real-Time Output Gap Estimates? Density Estimates for the Euro Area. National Institute of Economic and Social Research (Manuscript).

Nelson, E., Nikolov, K., 2003. UK Inflation in the 1970s and 1980s: the role of output gap mis-measurement. Journal of Economics and Business 55, 353-370.

Orphanides, A., 2001. Monetary policy rules based on real-time data. American Economic Review 91, 964-985.

Orphanides, A., 2003. The quest for prosperity without inflation. Journal of Monetary Economics 50, 633-663.

Orphanides, A., van Norden, S., 1999. The reliability of output gap estimates in real time. Board of Governors of the Federal Reserve System: Finance and Economics Discussion Series, 1999-38.

Orphanides, A., van Norden, S., 2002. The unreliability of output gap estimates in real time. The Review of Economics and Statistics 84, 569-583.

St-Amant, P., van Norden, S., 1998. Measurement of the output gap: a discussion of recent research at the Bank of Canada. Bank of Canada Technical Report 1998-79.

van Norden, S., 1995. Why Is It So Hard to Measure the Current Output Gap? Bank of Canada (Manuscript).

Watson, M., 2007. How accurate are real-time estimates of output trends and gaps? Federal Reserve Bank of Richmond Economic Quarterly 93, 143-161. 